\title{
IN SILICO ANALYSIS OF PHAG-LIKE PROTEIN IN RALSTONIA EUTROPHA H16, POTENTIALLY INVOLVED IN POLYHYDROXYALKANOATES SYNTHESIS
}

\author{
Melissa Uribe Acosta ${ }^{1}$, Andrés Felipe Villa Restrepo ${ }^{1}$ \\ 1 Grupo Biotransformación, Escuela de Microbiología, Universidad de Antioquia. Calle 67 n. 53-108, \\ laboratorio 5-226. Medellín, Colombia. \\ Correspondencia: melissa.uribe1@udea.edu.co
}

\begin{abstract}
Polyhydroxyalkanoates (PHA) are synthesised by bacteria as carbon storage material. The protein PhaG directs carbon from non-related carbon sources such as glycerol, metabolised through fatty acid de novo synthesis (FAS) pathway, with PHA synthesis. The gene that codifies for this protein has not yet been found in the genome of Ralstonia eutropha $\mathrm{H} 16$, a model organism. By bioinformatic comparison to already known PhaG proteins, a PhaG-like protein was found codified by gene H16_A0147 and presence of the gene was preliminary confirmed by PCR. This is the first study that shows the presence and characteristics of a PhaGlike protein in $R$. eutropha $\mathrm{H} 16$ and represents the first step for the identification of a connection between FAS and PHA pathways in this model bacterium. Further gene deletion and enzymatic activity studies are necessary to confirm this potential relationship, which could improve industrial PHA production and utilisation of agroindustrial residues such as glycerol.
\end{abstract}

Keywords: Polyhydroxyalkanoates, Ralstonia eutropha H16, non-related carbon sources, protein function prediction.

Recibido: 30 de Septiembre de 2019. Aceptado: 16 de Mayo de 2019

Received: September 30, 2019. Accepted: May 16, 2019

\section{ANÁLISIS IN SILICO DE UNA PROTEÍNA SIMILAR A PHAG EN RALSTONIA EUTROPHA H16 POTENCIALMENTE INVOLUCRADA EN LA SÍNTESIS DE POLIHIDROXIALCANOATOS}

RESUMEN

Los polihidroxialcanoatos (PHA) son sintetizados por las bacterias como material de reserva de carbono. La proteína PhaG dirige el carbono proveniente de fuentes de carbono no relacionadas como el glicerol, que son metabolizados a través de la síntesis de ácidos grasos de novo (FAS), hacia la síntesis de PHA. El gen que codifica esta proteína no ha sido aún encontrado en el genoma de Ralstonia eutropha H16, un organismo modelo. A través de la comparación con proteínas PhaG ya conocidas, una proteína similar a PhaG, fue encontrada siendo codificada por el gen H16_A0147 y la presencia del gen confirmada preliminarmente utilizando PCR. Este es el primer estudio que muestra la presencia y características de una proteína similar a PhaG en R. eutropha H16 y representa el primer paso en la identificación de una conexión entre las rutas metabólicas FAS y de PHA en esta bacteria modelo. Estudios de bloqueo de genes y actividad enzimática son necesarios para confirmar esta relación potencial que podría mejorar la producción industrial de PHA y la utilización de residuos agroindustriales como el glicerol.

Palabras clave: Polihidroxialcanoatos, Ralstonia eutropha H16, fuentes de carbono no relacionadas, predicción de función de proteínas.

Cómo citar este artículo: M. Uribe, A. Villa. "In silico analysis of phag-like protein in ralstonia eutropha H16, potentially involved in polyhydroxyalkanoates synthesis", Revista Politécnica, vol. 15, no.29 pp. 55-64, 2019. DOI: 10.33571/rpolitec.v15n29a5 


\section{INTRODUCTION}

Polyhydroxyalkanoates (PHA) are an environmentally friendly alternative to the excessively used petrochemical plastics since they are biodegradable and can be used for similar purposes such as manufacturing of packaging materials or biomedical devices. PHA are polyesters synthesised by bacteria as carbon storage compounds when levels of oxygen, nitrogen or phosphorus are low. PHA can be classified according to the amount of carbon atoms in the hydroxyacyl-CoA monomers as short-chainlength PHA ( 3 to 5) and medium-chain-length PHA (mlc-PHA) (6 to 14). The composition of the monomers depends on the microorganism and the carbon source used, since the latter can be transformed into hydroxyacyl-CoA precursors by different metabolic routes $[1,2,3]$.

Fatty acid de novo synthesis (FAS) pathway is particularly interesting because these carbon sources are generally present in inexpensive organic residues, such as glycerol, which is a byproduct of biodiesel production $[5,6,7]$. Additionally, the polymer produced through this pathway, mcl-PHA, can be used as a biodegradable alternative for elastomer and rubber in cosmetics, paint formulations and medical devices [8]. PhaG is the enzyme that allows this connection between FAS pathway and PHA synthesis by transforming the intermediate 3hydroxyacyl-ACP into 3-hydroxyacyl-CoA [5].

PhaG was characterised for the first time by Rehm et al. (1998) [5] in Pseudomonas putida KT2448 as a hydroxyacyl-CoA-ACP-transferase, however, Wang et al. (2012) [7] suggested that the PhaG protein function is rather a thioesterase. Bacteria missing this PhaG protein accumulated $85 \%$ polymer with octanoate as substrate but only $3 \%$ when gluconate, which is metabolised through FAS pathway, was provided as carbon source [5], indicating its importance for PHA synthesis from gluconate. Furthermore, PHA production from simple carbon sources was re-established in $P$. oleovorans ATCC 29347 and $P$. fragi [9] and augmented up to $40 \%$ in $P$. aeruginosa PAO1 [5], only by the insertion of the genes phaC + phaG or only phaG, respectively. PhaG protein has only been experimentally characterised and reported in Pseudomonas species, Burkholderia caryophylli and Aeromonas hydrophila [10], out of the 75 bacterial genera that have been reported as PHA producers [2].

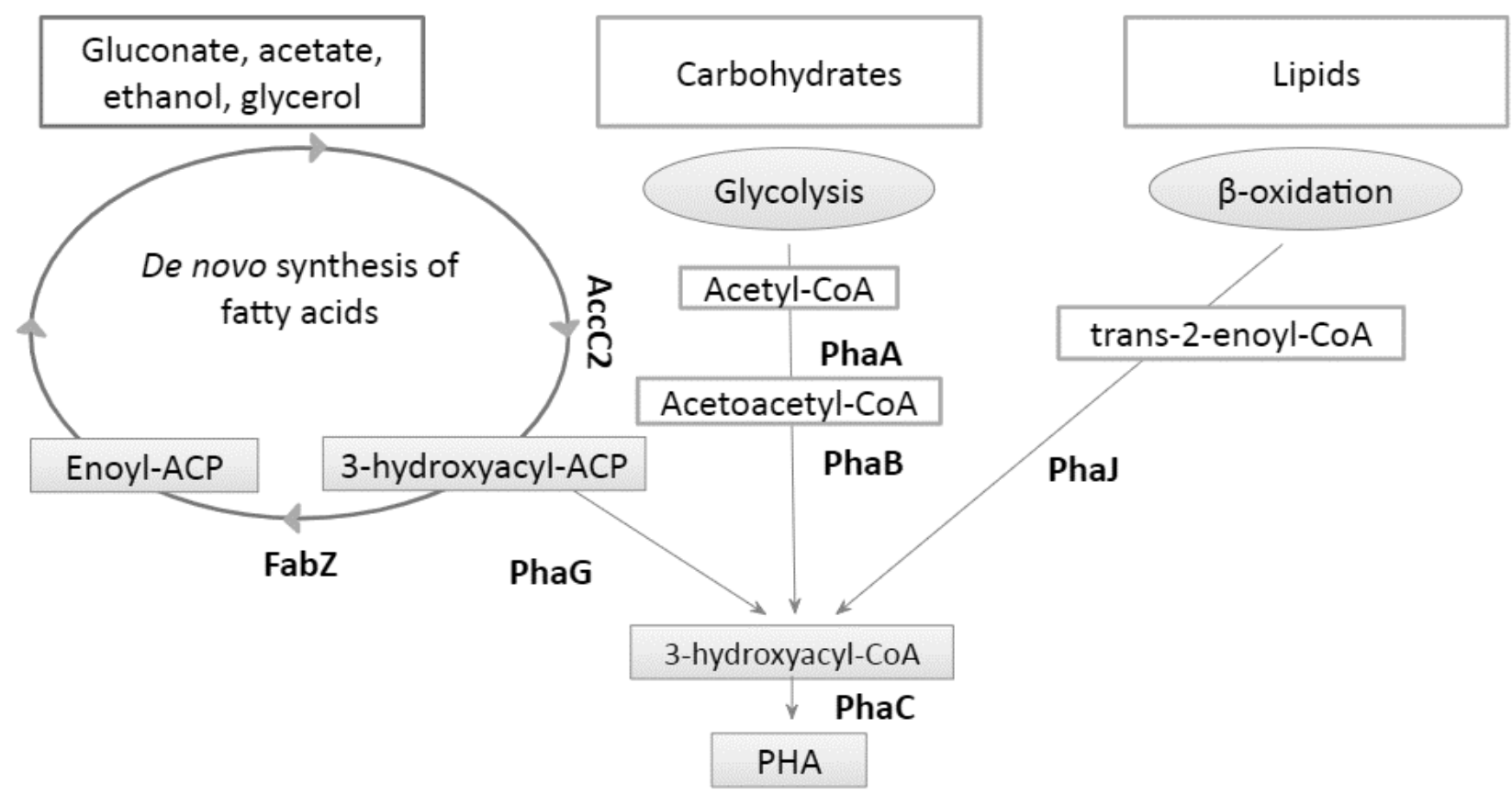

Fig. 1. Connection of central metabolic pathways with PHA metabolism. 
There has not been evidence that $R$. eutropha $\mathrm{H} 16$, the most well-studied bacterium regarding PHA metabolism and model for large-scale production, possesses a phaG homologue. However, $R$. eutropha $\mathrm{H} 16$ has also shown its ability to utilise alternative carbon sources such as gluconate, glycerol or acetate for PHA synthesis [11]. Peplinski et al. (2010) [12] reported a relationship between (FAS) and PHA synthesis, based on the upregulation of genes involved in FAS pathway, such as accC2 and fabG, when $R$. eutropha $\mathrm{H} 16$ grew on sodium gluconate as carbon source and produced PHA. Additionally, other studies have shown that deletion of up to 9 phaA homologues does not suppress PHA production from sodium gluconate in this bacterium $[13,14]$. These evidences suggest that $R$. eutropha $\mathrm{H} 16$ may possess proteins which are able to perform the same function as PhaG.

Proteins with $<50 \%$ similarity can be compared on the basis of conserved motifs which can reveal protein function even when this is not globally similar to any known protein [15]. Protein function prediction is a major issue in biology since the protein databases grow exponentially with the crescent availability of fast and inexpensive sequencing techniques while experimental protein characterisation techniques are still timeconsuming and expensive. Due to in silico analysis, novel and useful proteins can be targeted that will allow the development of new PHA production strategies. The goals of this research were: to identify genes in $R$. eutropha $\mathrm{H} 16$ codifying proteins with high similarity to PhaG, to analyse and compare those proteins in silico to all PhaG proteins that are already experimentally characterised and to preliminarily confirm the presence of the genes codifying these in silico predicted proteins.

\section{METHODOLOGY}

\section{In silico analysis and PhaG homologues characterisation}

Using PhaG protein sequence from $P$. putida KT2440 (Model PhaG protein [10]), accession number AAC34749.1, a standard and specialised protein BLAST (BLASTP) was carried on BacMap protein database, on both $R$. eutropha $\mathrm{H} 16$ chromosomes (Matrix: BLOSUM62, Mask: low complexity, Program: blastp, Database: Protein).
Only those proteins with similarity $>40 \%$ and evalue $\leq 1 \mathrm{e}-04$ were selected. After a literature search and selection for already characterised PhaG proteins [10, 16], 9 PhaG homologues were analysed using the tool MOTIF finder from the GenomeNet Database Resources of the Kyoto University Bioinformatics Center. PhaG proteins for PROSITE patterns, NCBI Conserved Domains (CDD) and Protein families (Pfam) were aligned using the UniProt alignment tool (www.uniprot.org/align) and conserved aminoacids related to known catalytic aminoacid residues in thioesterases were located manually. Using Membrane protein IdeNtificatioN withOUt explicit use of hydropathy profiles and alignments (MINNOU server), an image from the secondary structure of the proteins was generated.

\section{Culture conditions}

$R$. eutropha $\mathrm{H} 16$ was maintained on tryptic soy agar (TSA) plates. Individual colonies were inoculated in tryptic soy broth (TSB) and incubated at $30^{\circ} \mathrm{C}$ for $12 \mathrm{~h} .2 \mathrm{~mL}$ of cultures with OD600: 0,5, were centrifuged, supernatant was discarded and cell pellet was washed twice in $\mathrm{NaCl} 0,9 \%$ solution before DNA extraction.

\section{DNA extraction and $R$. eutropha $\mathrm{H} 16$ phaG-like gene amplification}

$R$. eutropha H16 DNA was used as a template for the development and optimisation of phaG-like genes amplification. DNA was obtained by using DNeasy Blood and Tissue Kit (Qiagen) according to the manufacturer's protocol for Gram negative bacteria. Primers targeting phaG-like gene H16_A0147 were designed and the desired sequence was sent to the company Eurofins scientific to be synthesised. A Polymerase chain reaction (PCR) with different annealing temperatures was carried out to determine the annealing temperature. PCR amplifications were performed in a $20 \mu \mathrm{L}$ reaction mixture containing $1 \mathrm{X}$ Taq buffer; $1.5 \mathrm{mM} \mathrm{MgCl} 2,0.2 \mathrm{mM}$ of dNTPs, $1 \mu \mathrm{M}$ of each primer, $0.03 \mathrm{U} / \mu \mathrm{L}$ of Taq DNA polymerase and $1 \mu \mathrm{L}$ of genomic DNA (25-30 ng). PCR conditions were: initial denaturation at $95^{\circ} \mathrm{C}$ for 30 $\mathrm{s}$; denaturation at $95{ }^{\circ} \mathrm{C}$ for $20 \mathrm{~s}$; annealing at 53$60{ }^{\circ} \mathrm{C}$ for $45 \mathrm{~s}$; extension at $72{ }^{\circ} \mathrm{C}$ for $60 \mathrm{~s}(30$ cycles) and final extension at $72{ }^{\circ} \mathrm{C}$ for $120 \mathrm{~s}$. Four negative controls with no DNA were included at annealing temperatures of $54,56,58$ and 60 . The resulting PCR products were visualised in $1 \%$ 
agarose gel and stained with $\mathrm{EZ}-\mathrm{Vision}^{\circledR}$ in gel solution.

\section{RESULTS}

\section{In silico analysis and PhaG homologues characterisation.}

Two proteins, one codified by a gene from chromosome 1 and one codified by a gene from chromosome 2 , were found with $\%$ sequence identity $>20$, \% positive substitutions $>40$ and evalue $<=1 \mathrm{e}-04$ when compared to $\mathrm{PhaG}$ sequence: (1) gene and locus tag H16_A014, with protein accession number in NCBI CAJ91299.1 presented $21 \%$ identity and $41 \%$ similarity with an e-value of $6 \times 10 \mathrm{e}-4$, is located in chromosome 1 and has a gene size of $843 \mathrm{bp}$. (2) gene $m h p C$ with locus tag H16_B1070 and protein accession number in NCBI CAJ95861.1 presented $22 \%$ identity and 40 $\%$ similarity with an e-value of $6 \times 10 \mathrm{e} 4$, is located in chromosome 2 and has a gene size of $795 \mathrm{bp}$.

According to Russell et al. (1997) [17] proteins that are able to perform the same function, either a remote homologue or analogue, can show less than $50 \%$ of sequence similarity due to shared active sites or conserved domains; the formal definition of remote homology is protein sequences that share an identity percentage of less than $25 \%$ [18]. mhpC gene is already annotated in $R$. eutropha $\mathrm{H} 16$ genome as aminoacrylate hydrolase and located in chromosome 2 while all PHA-related genes are located in chromosome 1 in $R$. eutropha $\mathrm{H} 16$ [11]; for those reasons, it was not included in further analysis as a potential PhaG analogue or remote homologue.

Already characterised $\mathrm{PhaG}$ proteins as well as H16_A0147 were individually tested for conserved domains and protein families. All PhaG homologues and H16_A0147 were found to have an $\alpha / \beta$ hydrolase 1 domain as the principal and only domain in CDD. No matches were found for any of the proteins when using the PROSITE database. All PhaG homologues, as well as H16_A0147, exhibit significant similarity to Pfam Abhydrolase 6 and Hydrolase_4 (Table 1). No PhaG homologue showed significant similarity to a transferase Pfam or CDD. Interestingly, PhaG from Pseudomonas sp. USM 4-55 as well as H16_A0147 showed significant similarity to a $\mathrm{PH} \overline{\mathrm{A}}$ depolymerase domain.

Table 1. E-values from PhaG homologues and R. eutropha H16_RS00705 compared to Pfam database.

\begin{tabular}{|l|r|r|r|r|}
\hline & Abhydrolase_1 & Abhydrolase_6 & Hydrolase_4 & \multicolumn{2}{l|}{$\begin{array}{l}\text { Accession } \\
\text { number }\end{array}$} \\
\hline Strains & $1.30 \mathrm{E}-28$ & $3.80 \mathrm{E}-17$ & $6.70 \mathrm{E}-14$ & CAJ91299.1 \\
\hline R. eutropha H16 (H16_A0147) & $5.40 \mathrm{E}-14$ & $2.40 \mathrm{E}-06$ & $9.90 \mathrm{E}-09$ & AAC34749.1 \\
\hline Pseudomonas sp. USM 4-55 & $2.00 \mathrm{E}-10$ & $5.10 \mathrm{E}-11$ & $4.20 \mathrm{E}-10$ & ACA03779.1 \\
\hline P. aeruginosa & $2.00 \mathrm{E}-10$ & $3.20 \mathrm{E}-08$ & $1.50 \mathrm{E}-07$ & AAF61903.1 \\
\hline P. stutzeri strain 1317 & $5.40 \mathrm{E}-14$ & $2.40 \mathrm{E}-06$ & $9.90 \mathrm{E}-09$ & AAM64206.2 \\
\hline P. nitroreducens strain 0802 & $8.70 \mathrm{E}-14$ & $6.50 \mathrm{E}-06$ & $3.60 \mathrm{E}-08$ & AAK71349.1 \\
\hline P. mendocina strain LZ & $1.30 \mathrm{E}-11$ & $8.60 \mathrm{E}-06$ & $1.60 \mathrm{E}-06$ & AAQ16175.1 \\
\hline P. oleovorans & $4.50 \mathrm{E}-13$ & $2.30 \mathrm{E}-06$ & $1.50 \mathrm{E}-08$ & AAF89663.1 \\
\hline Burkholderia caryophylli & $5.20 \mathrm{E}-10$ & $>1 \mathrm{E}-4$ & $3.50 \mathrm{E}-07$ & AAK71350.1 \\
\hline Pseudomonas sp. 61-3 & $7.10 \mathrm{E}-09$ & $>1 \mathrm{E}-4$ & $1.50 \mathrm{E}-08$ & BAB32432.1 \\
\hline P. fluorescens strain BM07 & $6.90 \mathrm{E}-07$ & $>1 \mathrm{E}-4$ & $2.00 \mathrm{E}-07$ & ACA60824.1 \\
\hline
\end{tabular}


$\alpha / \beta$ hydrolase superfamily is a large family of proteins where Thioesterases are included. Predicted secondary structures for $P$. putida KT 2447 PhaG and H16 A0147 are presented in Figure 2. Visually, predicted secondary structures are very similar among these two proteins in

\section{Confirmation of H16_A0147 gene presence}

A PCR product with around 800 bp was obtained using the designed primers on DNA extracted from

A

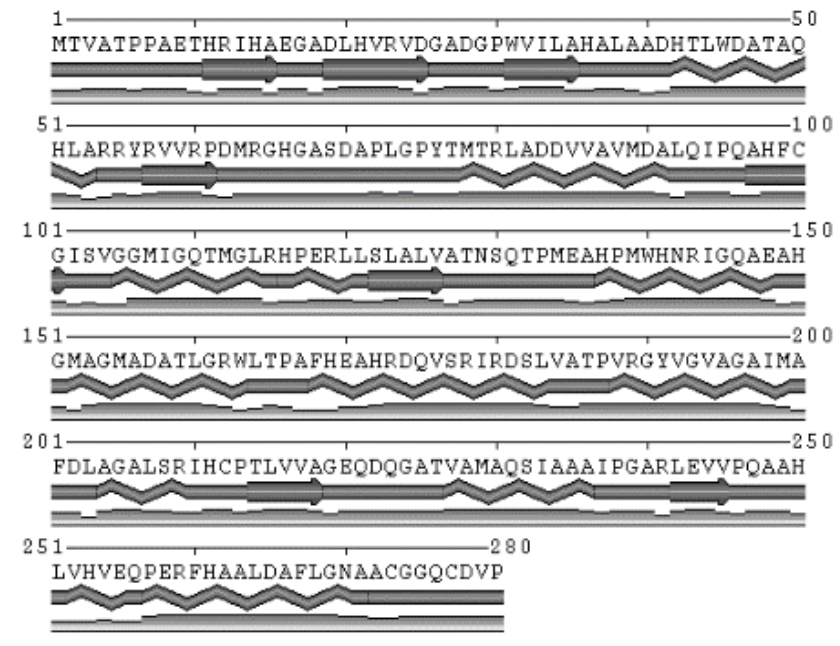

contrast with their low similarity percentages, further supporting that low global protein sequence similarity does not necessarily mean two proteins differ in their spatial arrangement, which is a key protein function determinant.

$R$. eutropha $\mathrm{H} 16$, in accordance with the in silico obtained information about H16_A0147 sequence (Table 2).

\section{B}

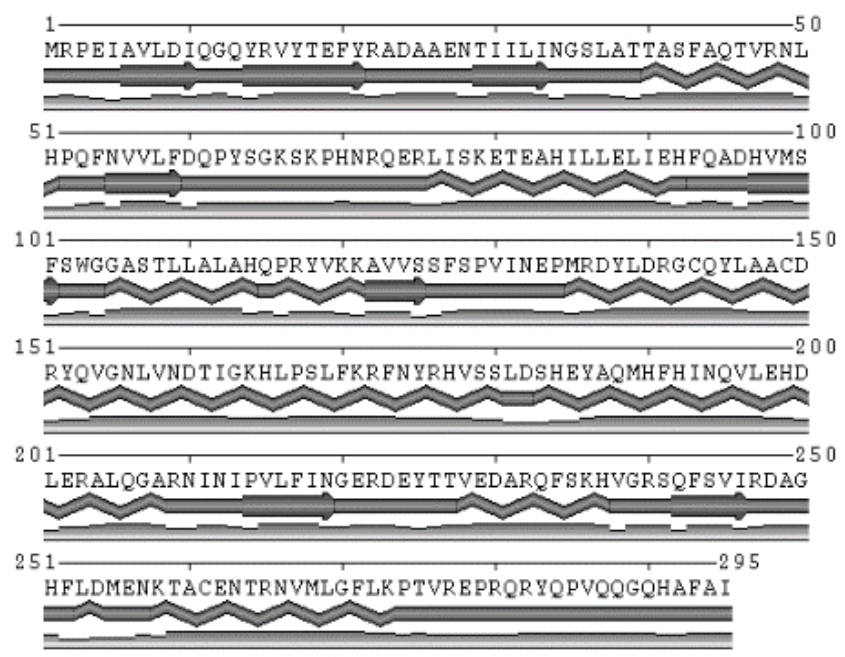

Fig. 2. Predicted secondary structure image generated with MINNOU Server [19], $\beta$-sheets are represented as arrows and $\alpha$-helices as waves. The third line indicates the confidence level of the predicted structure for that particular position.

Table 2. Amplification of a phaG-like gene from $R$. eutropha $\mathrm{H} 16$ genome on gradient temperature PCR.

\begin{tabular}{|c|c|c|c|c|c|c|c|c|}
\hline Forward primer & \multicolumn{8}{|c|}{ 5'-CACGCCACCAGCCGAAA-3' } \\
\hline Reverse primer & \multicolumn{8}{|c|}{ 5'-GATTGGATCCTCACGGAACGTCG -3 } \\
\hline $\begin{array}{l}\text { Annealing } \\
\text { temperature used }\end{array}$ & 53 & 54 & 55 & 56 & 57 & 58 & 59 & 60 \\
\hline $\begin{array}{l}\text { Presence/absence } \\
\text { of PCR product } \\
(+/-)\end{array}$ & - & - & - & - & - & + & + & + \\
\hline $\begin{array}{l}\text { Approximate PCR } \\
\text { product length } \\
\text { obtained (bp) }\end{array}$ & - & - & - & - & - & $\begin{array}{l}700- \\
1000\end{array}$ & $\begin{array}{l}700- \\
1000\end{array}$ & $\begin{array}{l}700- \\
1000\end{array}$ \\
\hline
\end{tabular}




\section{DISCUSSION}

\section{In silico analysis and PhaG homologues characterisation.}

The comparison of the Pfam analysis among the PhaG homologues and H16_A0147 indicates they belong to the same protein family, $\alpha / \beta$ hydrolase fold family, in spite of the low sequence similarity. This fact further suggests they might share catalytic active sites. Regarding the H16_A0147 gene, a thioesterase domain [20] was found in its sequence but no domain indicating a transferase function.

PhaG had been originally classified as an (R)-3hydroxyacyl- ACP-CoA transferase based on the ability of a partially purified extract to convert 3hydroxydecanoyl-CoA into 3-hydroxydecanoylACP when ACP was present [5]. However, overexpression of phaG in $E$. coli resulted in the extracellular accumulation of 3-hydroxydecanoic acid [7] and low PHA production (0,9 mg/L) compared to $E$. coli harbouring both phaG and PP0763 (25 mg/L) a predicted medium-chain-fattyacid CoA ligase [21]. Those results suggest that PhaG has rather thioesterase activity than transferase activity and separates the ACP moiety from the 3-hydroxyacyl before another enzyme, probably a ligase, catalyses the merging of the CoA moiety to form 3-hydroxyacyl-CoA. Our results are according to those from Wang et al. (2012) [21] and, since no transferase conserved domain was found, support the possibility that PhaG-like proteins in $R$. eutropha $\mathrm{H} 16$ perform a thioesterase function instead of a transferase function. Further studies are necessary in order to characterise the enzyme activity of this protein.

$\alpha / \beta$ hydrolase fold family is one of the largest groups of structurally related proteins. Thioesterases are included together with other hydrolytic enzymes such as acetylcholinesterases, carboxylesterases, dienelactones hydrolases, lipases, cutinases, serine carboxypeptidases, proline iminopeptidases, proline oligopeptidases and epoxide hydrolases, and also enzymes that require $\mathrm{HCN}, \mathrm{H}_{2} \mathrm{O}_{2}$ or $\mathrm{O}_{2}$ instead of $\mathrm{H}_{2} \mathrm{O}$ such as haloalkane dehalogenases, haloperoxidases and hydroxynitrile lyases [22] but the family also includes non-catalytic enzymes [23]. Thioesterases can hydrolyse the ester bond between a carbonyl group and a sulphur atom, the substrates include both CoA and ACP moieties, and are classified in
23 families with low sequence homology but similar tertiary structure [20].

The genome context was also analysed for H16_A0147 gene and compared with the location of phaG from P. putida KT 2447. H16_A0147 gene is surrounded upstream by other genes codifying hypothetical proteins, and downstream by gene pspE1 codifying a rhodanese-related sulphurtransferase and by bhmT codifying a methyltransferase (Figure 3). Unlike H16_A0147, phaG gene is located in the lagging strand and is surrounded upstream by a gene codifying a hypothetical protein and by gene $y d d V$ codifying a diguanylate cyclase. Downstream it is surrounded by gene $y c h M$ codifying a sulphate transporter and by a gene codifying a hypothetical protein (Figure 5). No similarities were found regarding the genome context of the two genes.

\section{Confirmation of PhaG-like gene presence}

Using the primers designed the in silico sequence to target specifically the gene H16_A0147, a PCR product was obtained with the expected length, at annealing temperatures of 58,59 and $60^{\circ} \mathrm{C}$, indicating lower temperatures are not optimal for primer alignment to the DNA targeted region. It is necessary to perform DNA sequencing on this PCR product in future studies to confirm that the sequence belongs to this particular gene. This confirmation could imply that this microorganism has an important element for the metabolic pathway implicated in the connection of FAS with PHA synthesis.

FAS pathway is necessary to provide fatty acids to the cell, required for phospholipid synthesis and, therefore, membrane formation for cell growth and division - functions that are highly active during exponential phase and decline during stationary phase when PHA production begins [12, 25, 26]. However, among these studies, Peplinski et al. (2010) [12] and Shimizu et al. (2013) [26] reported genes accC2 and fabG involved in FAS pathway were upregulated during $\mathrm{PHA}$ production in $P$. putida KT2447. These genes are expressed during the initial steps of FAS, and could allow accumulation of 3-hydroxyacyl-ACP, which is the substrate for PhaG. According to that, Wang et al. (2012) [21] demonstrated that phaG, phaC1 and phaC2 genes expression showed $\mathrm{n}$-fold induction of 220, 2.6 and 4.3 respectively, during PHA production phase in the same bacteria. We suggest 
this could be happening in $R$. eutropha $\mathrm{H} 16$ metabolism, and could be further studied by gene expression analysis targeting H16_A0147, accC2 and $f a b G$.

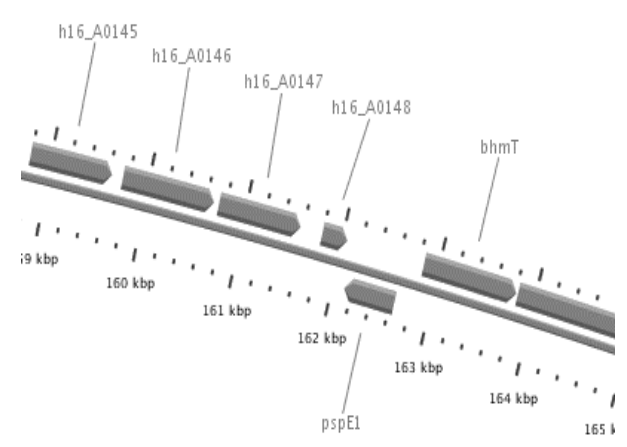

A

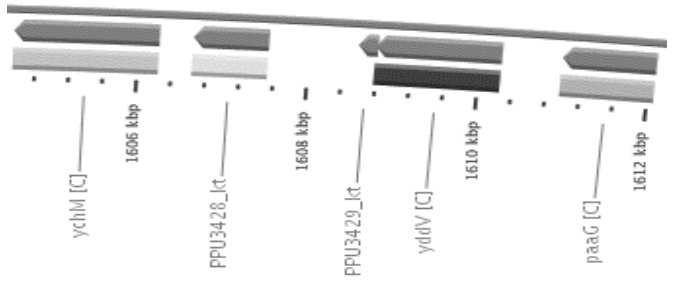

B

Fig. 3. Localisation and surrounding genes in their respective strains for (A) H16_A0147 in $R$. eutropha $\mathrm{H} 16$ genome and $(\mathrm{B})$ pha $\bar{G}\left(P P U 3428 \_k t\right)$ in $P$. putida KT2447 genome (Source: Bacmap [24]).

This is the first study that shows the presence and the characteristics of a putative phaG-like gene in $R$. eutropha $\mathrm{H} 16$ and represents the first step for the identification of a possible connection between FAS pathway and PHA synthesis in this novel bacterium. Further studies are necessary to confirm the potential relationship of the gene product of H16_A0147 gene with the PHA metabolism. Characterising a PhaG-like protein in $R$. eutropha $\mathrm{H} 16$ could allow the use of residues from biodiesel industry [6,7], or phenylacetic acid, which is a contaminating compound [27], for PHA synthesis in the future.

\section{CONCLUSIONS}

H16_A0147 was identified as a potential gene codifying for a PhaG-like protein with Thioesterase activity. Further studies are necessary to confirm this metabolic link. If this link is confirmed, expression of H16_A0147 may be manipulated in $R$. eutropha $\mathrm{H} 16$ for the production of PHA using waste products such as glycerol or contaminants like phenylacetic acid as carbon sources.

\section{ACKNOWLEDGEMENTS}

Carolina Ramírez, Luisa Múnera, Dr. Nancy Pino, the School of Microbiology, laboratory GDCON, all from University of Antioquia, and four anonymous evaluators contributed to this study and are gratefully acknowledged.

\section{REFERENCES}

[1] Aldor I.S. and Keasling, J.D. (2003). Process Design for Microbial Plastic Factories: Metabolic Engineering of Polyhydroxyalkanoates. Curr. Opin. Biotechnol. 14 475-483. DOI: 10.1016/j.copbio.2003.09.002

[2] Reddy, C.S.K. Ghai, R., Rashmi. and Kalia, V.C. (2003). Polyhydroxyalkanoates: An Overview. Biores Tech 87, 137-146. DOI: 10.1016/S09608524(02)00212-2

[3] Urtivia, V., Villegas, P., González, M. and Seeger, M. (2014). Bacterial Production of the Biodegradable Plastics Polyhydroxyalkanoates. Intern J Biol Macromol. 70: 208-213. DOI: 10.1016/j.ijbiomac.2014.06.001

[4] Lau, N., Foong, C.P., Kurihara, Y., Sudesh, K. and Matsui, M. (2014). RNA-Seq Analysis Provides Insights for Understanding Photoautotrophic Polyhydroxyalkanoate Production in Recombinant Synechocystis Sp. PLOS one. Vol 9(1). DOI: 10.1371/journal.pone.0086368

[5] Rehm, B.H.A., Kruger, N. and Steinbuchel, A. (1998). A New Metabolic Link between Fatty Acid de novo Synthesis and Polyhydroxyalkanoic Acid Synthesis: The phaG Gene from Pseudomonas putida KT2440 Encodes a 3-hydroxyacyl- acyl carrier Protein-coenzyme a Transferase. J. Biol. 
Chem. 273:24044-24051. DOI: $10.1074 / j b c .273 .37 .24044$

[6] Nomura, C.T., Tanaka, T., Eguen, T.E., Appah, A.S., Matsumoto, K., Taguchi, S., Ortiz, L. and Doi, Y. (2008). FabG Mediates Polyhydroxyalkanoate Production from Both Related and Nonrelated Carbon Sources in Recombinant Escherichia coli LS5218. Biotechnol. 24: 42-351. DOI: 10.1021/bp070303y

[7] Wang, Q., Zhuang, Q., Liang, Q. and QI, Q. (2013). Polyhydroxyalkanoic Acids from Structurally-unrelated Carbon Sources in Escherichia coli. Appl Microbiol Biotechnol. Vol 97:3301-3307. DOI: 10.1007/s00253-013-4809-x

[8] Leong, Y.K., Show P.L., Ooi, C.W., Ling, T.C. and Lan, J.C. (2014). Current Trends in Polyhydroxyalkanoates (PHAs) Biosynthesis: Insights from the Recombinant Escherichia coli. J Biotech 180, 52-65. DOI: 10.1016/j.jbiotec.2014.03.020

[9] Fiedler, S., Steinbuchel, A. and Rehm, B.H. (2000). PhaG-Mediated Synthesis of Poly(3Hydroxyalkanoates) Consisting of Medium-ChainLength Constituents from Nonrelated Carbon Sources in Recombinant Pseudomonas fragi. Appl. Environ. Microbiol. 66(5):2117-2124. DOI: 10.1128/aem.66.5.2117-2124.2000

[10] Röttig, A., and Steinbüchel, A. (2013). Acyltransferases in Bacteria. Microbiol Mol Bio Reviews: $\quad M M B R, \quad 77(2), \quad 277-321 . \quad$ DOI: 10.1128/MMBR.00010-13

[11] Pohlmann, A., Fricke, W. F., Reinecke, F., Kusian, B., Liesegang, H., Cramm, R., Eitinger, T., Ewering, C., Potter, M., Schwartz, E., Strittmatter, A., Voss, I., Gottschalk, G., Steinbuchel, A., Friedrich, B. and Bowien, B. (2006). Hydrogenbased Biotechnology: Genome Sequence of the Bioplastic-producing "Knallgas" Bacterium Ralstonia eutropha H16. Nat Biotechnol 24, 12571262. DOI: $10.1038 / \mathrm{nbt} 1244$

[12] Peplinski, K., Ehrenreich, A., Doring, C., Bomeke, M., Reinecke, F., Hutmacher, C. and Steinbuchel, A. (2010). Genome-wide Transcriptome Analyses of the 'Knallgas' Bacterium Ralstonia eutropha $\mathrm{H} 16$ with Regard to
Polyhydroxyalkanoate Metabolism. Microbiology, 156: 2136-2152. DOI: 10.1099/mic.0.038380-0

[13] Lindenkamp, N., Peplinski, K., Volodina, E., Ehrenreich, A. and Steinbuchel, A. (2010). Impact of Multiple Beta-Ketothiolase Deletion Mutations in Ralstonia eutropha $\mathrm{H} 16$ on the Composition of 3Mercaptopropionic Acid-Containing Copolymers. Appl. Environ. Microbiol. Vol. 76(16): 5373-5382. DOI: 10.1128/AEM.01058-10

[14] Lindenkamp, N., Volodina, E. and Steinbuchel, A. (2012). Genetically Modified Strains of Ralstonia eutropha H16 with Beta-Ketothiolase Gene Deletions for Production of Copolyesters with Defined 3-Hydroxyvaleric Acid Contents. App. Environ. Microbio. 78(15):5375-83. DOI: 10.1128/AEM.00824-12

[15] Nevill-Manning, C., Wu, T. and Brutlag, D. (1998). Highly Specific Protein Sequence Motifs for Genome Analysis. Proc. Natl Acad. Sci. 95:58655871. DOI: 10.1073/pnas.95.11.5865

[16] Arsad H. (2009). Cloning and Characterisation of (R)-3-hydroxyacyl-acyl Carrier Proteincoenzyme A Transferase Gene (phaG) from Pseudomonas sp. USM 4-55. Trop. Life. Sci. Res. 20(2):1-14.

[17] Russell, B., Saqi, M.A., Sayle, R.A., Bates, P.A. and Sternberg, M.J.E. (1997). Recognition of Analogous and Homologous Protein Folds: Analysis of Sequence and Structure Conservation. J. Mol. Biol. 269:423-439. DOI: 10.1006/jmbi.1997.1019

[18] Bedoya, O. and Tischer, I. (2015). Reducing Dimensionality in Remote Homology Detection Using Predicted Contact Maps. Comput. Biol. Med. 59:64-72. 10.1016/j.compbiomed.2015.01.020

[19] Cao, B., Porollo, A., Adamczak, R., Jarrell, M. and Meller, J. (2006). Enhanced Recognition of Protein Transmembrane Domains with Predictionbased Structural Profiles. Bioinformatics. 22:303-9. DOI: 10.1093/bioinformatics/bti784

[20] Cantu, D.C., Chen, Y. and Reilly, P.J. (2010). Thioesterases: A New Perspective Based on their Primary and Tertiary Structures. Protein Sci. 19:1281-1295. DOI: 10.1002/pro.417 
[21] Wang, Q., Tappel, R.C., Zhu, C. and Nomura, C.T. (2012). Development of a New Strategy for Production of Medium-chain-length Polyhydroxyalkanoates by Recombinant Escherichia coli via Inexpensive Non-fatty Acid Feedstocks. Appl Environ Microbiol. 78(2):519-27. DOI: 10.1128/AEM.07020-11

[22] Bugg, T.D. (2004). Diverse Catalytic Activities in the Alphabeta-hydrolase Family of Enzymes: Activation of $\mathrm{H} 2 \mathrm{O}, \mathrm{HCN}, \mathrm{H} 2 \mathrm{O} 2$, and $\mathrm{O} 2$. Bioorg Chem. 32(5):367-375. DOI: 10.1016/j.bioorg.2004.05.005

[23] Nardini, M. and Dijkstra, B.W. (1999). $\alpha / \beta$ Hydrolase Fold Enzymes: The Family Keeps Growing. Curr Opin Struct Biol. 9(6):732-737.

[24] Stothard, P., Van Domselaar, G., Shrivastava, S., Guo, A., O'Neill, B., Cruz, J., Ellison, M. and Wishart, D.S. (2005). BacMap: An Interactive Picture Atlas of Annotated Bacterial Genomes. Nucleic Acids Res 33:D317-D320.

[25] Brigham, C.J., Speth, D.R., Rha, C. and Sinskeya, A.J. (2012). Whole-Genome Microarray and Gene Deletion Studies Reveal Regulation of the Polyhydroxyalkanoate Production Cycle by the Stringent Response in Ralstonia eutropha H16. App Environ Microbiol. 78;8033-8044. DOI: 10.1128/AEM.01693-12

[26] Shimizu, R., Chou, K., Orita, I., Suzuki, Y., Nakamura, S. and Fukui, T. (2013). Detection of Phase-dependent Transcriptomic Changes and Rubisco-mediated CO2 Fixation into Poly (3hydroxybutyrate) under Heterotrophic Condition in Ralstonia eutropha H16 Based on RNA-seq and Gene Deletion Analyses. BioMed Cen Microbiol. 13:169. DOI: 10.1186/1471-2180-13-169

[27] Tobin, K.M., O'Leary, N.D., Dobson, A.D. and O'Connor, K.E. (2007). Effect of Heterologous Expression of phaG [(R)-3-hydroxyacyl-ACP-CoA transferase] on Polyhydroxyalkanoate Accumulation from the Aromatic Hydrocarbon Phenylacetic Acid in Pseudomonas species. FEMS Microbiol Lett. 268(1):9-15. DOI: 10.1111/j.15746968.2006.00607.x 
